\title{
ФАКТОРИ РИЗИКУ В ПРОГНОЗУВАННІ ВИХОДУ ХІРУРГІЧНОГО ЛІКУВАННЯ ПРОЛІФЕРАТИВНОЇ ДІАБЕТИЧНОЇ РЕТИНОПАТІЇ
}

\author{
С. О. Риков, А. М. Рубан, А. Ю. Зольнікова \\ Національна медична академія післядипломної освіти імені П. А. Шупика \\ У статті представлені результати визначення прогностичної цінності впливу факторів ризику на результат хірур- \\ гічного втручання у хворих з проліферативною діабетичною ретинопатією. \\ Ключові слова: прогнозування результату, фактори ризику, вітректомія, проліферативна діабетична ретинопатія.

\section{ФАКТОРЫ РИСКА В ПРОГНОЗИРОВАНИИ ИСХОДА ХИРУРГИЧЕСКОГО ЛЕЧЕНИЯ ПРОЛИФЕРАТИВНОЙ ДИАБЕТИЧЕСКОЙ РЕТИНОПАТИИ} \\ С. А. Рыков, А. Н. Рубан, А. Ю. Зольникова \\ Национальная медицинская академия последипломного образования имени П. А. Шупика \\ В статье представлены результаты определения прогностической ценности влияния факторов риска на резуль- \\ тат хирургического лечения пациентов с диабетической пролиферативной ретинопатией.
}

Ключевые слова: прогнозирование результата, факторы риска, витрэктомия, пролиферативная диабетическая ретинопатия.

\section{PREDICTIVE CLINICAL FEATURES OF SURGICAL TREATMENT FOR PROLIFERATIVE DIABETIC RETINOPATHY}

\author{
S. O. Rykov, A. M. Ruban, A. Yu. Zolnikova \\ National Medical Academy of Post-Graduate Education by P. L. Shupyk
}

The article describes the results in detection different factors that may predict visual outcome after vitrectomy for proliferative diabetic retinopathy.

Key words: predictive factors, vitrectomy, proliferative diabetic retinopathy.

Вступ. Проблема цукрового діабету (I ІД) в даний час стає все більш актуальною. Згідно $з$ даними ВОО3, у 2003 році загальна кількість хворих на цукровий діабет у світі становила близько 189 млн чоловік. Щорічно ця цифра збільшується на 5-7 \% [1]. За прогнозами, у 2025 році їх кількість перевищить 324 млн людей. В Україні офіційно зареєстровано близько 1,5 млн хворих на цукровий діабет, проте вважається, що справжня захворюваність $є$ значно більшою. Головною причиною інвалідизації хворих $\epsilon$ діабетична проліферативна ретинопатія (ДПР) - ускладнення ІД, що призводить до загибелі сітківки, зорового нерва та стійкої й незворотної сліпоти. На їі частку припадає 80-90 \% усієї інвалідності по зору, зумовленої цукровим діабетом [2].

Впроваджене в клінічну практику у 1972 році Я. Масьешег (США), хірургічне лікування (вітрек(C) С. О. Риков, А. М. Рубан, А. Ю. Зольнікова томія) діабетичної проліферативної ретинопатії показане при: інтравітреальному крововиливі, макулярному набряку, тракційному або регматогенному відшаруванні сітківки, передній гіалоїдній проліферації. Мета операції полягає в видаленні з порожнини ока крововиливів, фіброваскулярних мембран та задньої гіалоїдної мембрани з поверхні сітківки, проведенні ендолазерокоагуляції та, при необхідності, видаленні кришталика та імплантації штучної інтроокулярної лінзи [3]. Впровадження в останні роки малоінвазивної хірургії, оптичних систем широкутової візуалізації очного дна, використання інгібіторів ендотеліального фактора росту (VEGF), вітреоретинальних барвників дозволило значно підвищити ефективність вітреоретинальних операцій $[4,5,6,7]$. Водночас, це не дозволило повністю уникнути появи тяжких інтрата післяопераційних ускладнень (крововиливи, відша- 
рування сітківки, неоваскулярна глаукома, атрофія сітківки та зорового нерва), які можуть призвести до тяжкої втрати зору [8].

На сьогоднішній день результат хірургічного лікування пацієнтів з проліферативною діабетичною ретинопатією є недостатньо прогнозованим і визначається багатьма чинниками. Серед них найважливішими, за даними літератури, є соматичний стан хворого, офтальмологічний статус та інтраопераційні особливості хірургії $[9,10]$. В пошуках вирішення цієї непростої проблеми увагу дослідників усе більше й більше привертають нові перспективні напрямки, серед яких одне 3 провідних місць належить фізіологічній кібернетиці та клінічному прогнозуванню [11].

Метою дослідження було визначення прогностичної чинності найважливіших клінічних ознак як факторів ризику для прогнозування перебігу та результату хірургічного лікування пацієнтів з проліферативною діабетичною ретинопатією.

Матеріали та методи. Проведено ретроспективне дослідження 80 операцій (вітректомій) у неселективній когорті 80 пацієнтів (80 очей) з проліферативною діабетичною ретинопатією (ПДР) з метою визначити результати операції, рівень ускладнень та можливі прогностичні фактори кінцевого зору. Загальну групу склали пацієнти з вітреальним крововиливом, тракційним або тракційно-регматогенним відшаруванням сітківки. До групи не увійшли: пацієнти 3 первинним регматогенним відшаруванням сітківки, увеїтами або травмою. Мінімальний термін спостереження становив 6 місяців.

Тридцять вісім (47\%) з 80 очей мали максимально кориговану гостроту зору (МКГЗ) < 0,1 на кінцевому огляді, що визначалось як незадовільний функціональний результат операції (несприятлива група), та 42 (52\%) ока мали МКГЗ > 0,1 (сприятлива група). Чоловіків було 45 (56,3 \%), жінок - 35 (43,8 \%). В групу увійшли 53 (66,2\%) пацієнти з 1 типом цукрового діабету, 27 (33,8 \%) пацієнтів з 2 типом цукрового діабету, тривалість діабету $>15$ років відмічена у 74 (94,9\%) пацієнтів, та $<15$ років у $6(5,1 \%)$. Вік пацієнтів становив від 17 до 71 року, серед яких 29 пацієнтів (36,3 \%) були молодші 50 років, та 51 пацієнт $(63,7 \%)$ старший 50 років.

Доопераційне обстеження включало: визначення гостроти зору, біомікроскопію, офтальмоскопію, статичну та динамічну периметрію, тонометрію, ультразвукове сканування (при неможливості огляду очного дна), флуоресцентну ангіографію (для визначення макулярної ішемії сітківки), оптичну когерентну томографію (для діагностики макулярного набряку, розриву, вітреомакулярної тракціi). Гостроту зору визначали за таблицею Сівцева-Головіна.

Операції виконувались одним хірургом (РАМ) за методою 3-портової вітректомії (моно- або бімануальною технікою) з використанням різних калібрів інструментів 20/23/25G. Видалялось центральне склоподібне тіло, проводилось усунення передньо-задніх тракцій та максимально повне видалення фіброваскулярних мембран та задньої гіалоїдної мембрани технікою деламінації, сегментації або висічення «єдиним блоком». При необхідності проводилась панретинальна ендолазерокоагуляція. Для візуалізації очного дна використовували ширококутову систему BIOM (Oculus, Germany) або OFFISS (Topcon, Japan). При необхідності проведення хірургічних маніпуляцій на макулярній ділянці сітківки ми використовували контактні лінзи (Dorc, Netherlands). В більшості випадків проводилась одночасна факоемульсифікація кришталика з імплантацією м'якої ІОЛ. Силіконова або газова тампонада проводилась за визначенням хірурга.

Пошук факторів ризику визначався імовірністю виникнення незадовільного кінцевого функціонального результату операції при наявності або відсутності ознаки. Обчислення прогностичної значимості ознак грунтувалося на критерії Стьюдента в модифікації Амосова зі співавторами і полягало в порівнянні частоти несприятливого результату у хворих при наявності досліджуваної ознаки з частотою несприятливого результату у всіх хворих, обстежених на даний показник. Для цього аналізували 145 ознак, що включали дані анамнезу, клінічного обстеження, лабораторних, спеціальних й інструментальних методів [12].

\section{Результати та їх обговорення.}

На підставі дослідження й аналізу 145 клінічних ознак було відібрано 33 чинники, які характеризують загальний стан, офтальмологічний статус пацієнта, а також інтраопераційні чинники, найбільш значимі для прогнозування результату операції (табл. 1).

Фактори, представлені з позитивними значеннями, можуть мати тільки негативне значення для прогнозу, фактори із знаком $\ll$ позитивні для прогнозу. Прогноз визначали сумою балів, що характеризують прогностичну важливість симптомів, виявлених у хворих, та інтраопераційних методик. Надалі число прогностичних ознак можна буде скоротити шляхом перевірки кореляційних зв'язків та виключення менш значимих.

Проведений аналіз засвідчив, що такі загальні передопераційні фактори як відсутність повної компенсації цукрового діабету, тривалість цукрового діабе- 
Таблиця. 1. Прогностична значимість факторів, які визначають результат хірургічного лікування проліферативної діабетичної ретинопатії (N- чисельність загальної групи, п- чисельність несприятливої групи)

\begin{tabular}{|c|c|c|c|c|c|c|c|}
\hline \multirow[b]{2}{*}{ Фактор ризику } & \multirow[b]{2}{*}{$\mathrm{N}$} & \multicolumn{4}{|c|}{ Частота несприятливого наслідку, \% } & & \multirow{2}{*}{$\begin{array}{c}\text { Значимість } \\
\text { у балах }\end{array}$} \\
\hline & & $\begin{array}{l}\text { загальна } \\
\text { група }\end{array}$ & & $\begin{array}{l}\text { несприятлива } \\
\text { група }\end{array}$ & & & \\
\hline \multicolumn{8}{|c|}{ Загальні фактори } \\
\hline Субкомпенсований загальний стан & 79 & 58,2 & 5,6 & 83,8 & 6,1 & 37 & 3,1 \\
\hline Тривалість діабету більш ніж 15 років & 78 & 94,9 & 2,5 & 100 & 0 & 37 & 2,1 \\
\hline Гіпоглікемія & 79 & 22,8 & 4,7 & 45,9 & 8,2 & 37 & 2,4 \\
\hline Енцефалопатія & 80 & 58,2 & 5,6 & 75,7 & 7,1 & 38 & 2,0 \\
\hline Ниркова недостатність & 80 & 73,4 & 5,0 & 100 & 0 & 38 & 5,4 \\
\hline Переміжна кульгавість & 80 & 26,6 & 5,0 & 48,6 & 8,2 & 38 & 2,3 \\
\hline Втрата чутливості кінцівок & 80 & 46,8 & 5,6 & 67,6 & 7,7 & 38 & 2,2 \\
\hline Набряки кінцівок & 80 & 45,6 & 5,6 & 83,8 & 6,1 & 38 & 4,6 \\
\hline Глюкозурія & 80 & 62,0 & 5,5 & 94,6 & 3,7 & 38 & 4,9 \\
\hline Ацетонурія & 80 & 17,7 & 4,3 & 35,1 & 7,9 & 38 & 2,0 \\
\hline Альбумінурія & 80 & 68,4 & 5,2 & 94,6 & 3,7 & 38 & 4,1 \\
\hline Гемоглобін менше 100 г/л & 80 & 19,0 & 4,4 & 62,2 & 8,0 & 38 & 4,7 \\
\hline \multicolumn{8}{|c|}{ Інтраопераційні (|іактори } \\
\hline $\begin{array}{l}\text { Неповне видалення фіброваскулярних } \\
\text { мембран }\end{array}$ & 80 & 38,8 & 5,5 & 63,2 & 7,8 & 38 & 2,6 \\
\hline Мономануальна хірургічна техніка & 80 & 78,8 & 4,6 & 94,8 & 3,7 & 38 & 2,8 \\
\hline Гідростатичний гемостаз більш ніж 1 хв & 80 & 57,6 & 5,5 & 89,5 & 5,0 & 38 & 4,3 \\
\hline Ендотампонада повітрям не виконувалась & 80 & 62,5 & 5,4 & 86,8 & 5,5 & 38 & 3,2 \\
\hline $\begin{array}{l}\text { Тимчасова тампонада перфтордекаліном } \\
\text { виконувалась }\end{array}$ & 80 & 50,0 & 5,6 & 13,2 & 5,5 & 38 & 4,7 \\
\hline Тривалість операції більш ніж 1 година & 80 & 40,0 & 5,5 & 78,9 & 6,6 & 38 & 4,5 \\
\hline $\begin{array}{l}\text { Ендолазеркоагуляція: } \\
\text { повна; неповна }\end{array}$ & 80 & $\begin{array}{l}41,3 \\
52,5\end{array}$ & $\begin{array}{l}5.5 \\
5.6\end{array}$ & $\begin{array}{l}10,5 \\
84,5\end{array}$ & $\begin{array}{l}5,0 \\
5,9 \\
\end{array}$ & 38 & $\begin{array}{c}-4,2 \\
4,0\end{array}$ \\
\hline $\begin{array}{l}\text { Техніка видалення мембран: } \\
\text { деламінація; }\end{array}$ & 80 & 33,8 & 5,3 & 15,8 & 6,0 & 38 & $-2,3$ \\
\hline Малоінвазивна техніка $(23 \mathrm{G} / 25 \mathrm{G})$ * & & & & & & & $-4,5$ \\
\hline Інтравітреальне введення інгібітора VEGF * & & & & & & & $-4,5$ \\
\hline \multicolumn{8}{|c|}{ Офтальмологічний статус } \\
\hline Максимально коригована гострота зору <0,05 & 80 & 74,3 & 5,1 & 86,8 & 5,5 & 38 & 2,1 \\
\hline $\begin{array}{l}\text { Загальне поле зору (градуси): } \\
<300 ; \\
301-400 ; \\
>400\end{array}$ & 80 & $\begin{array}{l}45,0 \\
38,0 \\
16,3 \\
\end{array}$ & $\begin{array}{l}3,0 \\
5,4 \\
4,1 \\
\end{array}$ & $\begin{array}{l}84,2 \\
13,2 \\
2,6\end{array}$ & $\begin{array}{l}6,0 \\
5,5 \\
2,6\end{array}$ & 38 & $\begin{array}{l}4,8 \\
-3,2 \\
-2,8\end{array}$ \\
\hline Повільна реакція зіниці на світло & 80 & 56,3 & 5,6 & 81,6 & 6,3 & 38 & 3,0 \\
\hline $\begin{array}{l}\text { Тракційне відшарування сітківки за типом } \\
\text { «площинна» }\end{array}$ & 70 & 21,4 & 4,9 & 40,0 & 8,3 & 35 & 2,0 \\
\hline $\begin{array}{l}\text { Зони неперфузії сітківки: } \\
2 \text { квадранти; } \\
3 \text { квадранти; } \\
4 \text { квадранти }\end{array}$ & 80 & $\begin{array}{l}26,3 \\
22,5 \\
23,8\end{array}$ & $\begin{array}{l}4,9 \\
4.7 \\
4.8 \\
\end{array}$ & $\begin{array}{r}7,9 \\
42,1 \\
50,0 \\
\end{array}$ & $\begin{array}{l}4,4 \\
8,0 \\
8,1 \\
\end{array}$ & 38 & $\begin{array}{l}-3,0 \\
2,1 \\
3,0\end{array}$ \\
\hline $\begin{array}{l}\text { Попередня лазерна коагуляція: } \\
\text { повна; } \\
\text { не виконана }\end{array}$ & 80 & $\begin{array}{l}17,5 \\
32,5\end{array}$ & $\begin{array}{l}4,3 \\
5,2 \\
\end{array}$ & $\begin{array}{c}5,3 \\
60,5 \\
\end{array}$ & $\begin{array}{l}3,6 \\
7,9\end{array}$ & 38 & $\begin{array}{l}-2,2 \\
3,0 \\
\end{array}$ \\
\hline Центральна скотома & 80 & 70,0 & 5,1 & 94,7 & 3,6 & 38 & 3,9 \\
\hline Аферентний зіничний дефект & 79 & 34,2 & 5,3 & 62,2 & 8,0 & 37 & 2,9 \\
\hline Медикаментозний мідріаз менше ніж 4 мм & 80 & 35,0 & 5,3 & 65,8 & 7,7 & 38 & 3,3 \\
\hline
\end{tabular}


Продовження табл. 1

\begin{tabular}{|c|c|c|c|c|c|c|c|}
\hline \multirow[b]{2}{*}{ Фактор ризику } & \multirow[b]{2}{*}{$\mathrm{N}$} & \multicolumn{4}{|c|}{ Частота несприятливого наслідку, \% } & \multirow[b]{2}{*}{$\mathrm{n}$} & \multirow{2}{*}{$\begin{array}{c}\text { Значимість } \\
\text { у балах }\end{array}$} \\
\hline & & $\begin{array}{c}\text { загальна } \\
\text { група }\end{array}$ & $\mathrm{m}$ & $\begin{array}{c}\text { несприятлива } \\
\text { група }\end{array}$ & $\mathrm{m}$ & & \\
\hline Рубеоз райдужки & 80 & 21,3 & 4,6 & 44,7 & 8,1 & 38 & 2,5 \\
\hline Тракційне відшарування макули & 80 & 75,3 & 4,8 & 92,1 & 4,4 & 38 & 2,6 \\
\hline Атрофія зорового нерва & 80 & 32,5 & 5,2 & 65,8 & 7,74 & 38 & 3,6 \\
\hline Попереднє введення інгібітора VEGF & 80 & 17,5 & 4,3 & 0 & 0 & 38 & $-4,5$ \\
\hline
\end{tabular}

ту більше 15 років, гіпоглікемія, ниркова недостатність, переміжна кульгавість, втрата чутливості кінцівок, набряки кінцівок, альбумінурія, концентрація гемоглобіну нижче 100 г/л мають суттєве негативне значення на результат хірургічного лікування.

Разом з тим, вік пацієнта на момент операції, стать, тип цукрового діабету, добова дозу інсуліну, енцефалопатія, інсульт, інфаркт міокарда, ішемічна хвороба серця, гіпертонічна хвороба, проведена ампутація, некроз пальця, трофічні виразки, глюкозурія, ацетонурія, концентрація глюкози крові не мали суттєвого негативного впливу на результат операції.

Серед передопераційних чиників, які характеризують офтальмологічний статус пацієнта і мають негативний вплив на результат операції, нами були визначені: загальне поле зору менше 300 градусів, максимально коригована гострота зору менше 0,05, повільна реакція зіниці на світло, атрофія зорового нерва, «площиний» тип тракційного відшарування сітківки, відсутність перфузії сітківки в 4-х квадрантах, не виконана попередньо панретинальна лазерокоагуляція сітківки, наявність центральної скотоми, аферентного зіничного дефекту Маркуса-Гуна, максимальний медикаментозний мідріаз менше 4 мм, рубеоз райдужки, відшарування макулярної сітківки.

Зміни внутрішньоочного тиску, стан кришталика, наявність штучного кришталика та методика його видалення (факоемульсифікація або екстракапсулярна екстракція), ступінь відшарування склоподібного тіла, наявність заднього вітреошизису, синехій, субмакулярної проліферації, тракційно-регматогенного відшарування сітківки, макулярний розрив, премакулярний крововилив, макулярний набряк, тип проліферації, виконання операції на єдиному оці, наявність попередньо проведеного оперативного втручання за отриманими нами даними не мали суттєвого негативного значення для прогнозу результату операції.

Аналіз прогностичної інформативності інтраопераційних факторів показав, що мономануальна техніка хірургії, неповне або часткове видалення фіброваскулярних мембран, використання під час операції перфтордекаліну, тривалість операції більше 1 годи- ни, невикористання повітряної ендотампонади сітківки, тривалість гідростатичного гемостазу більше 1 хвилини, проведення неповної інтраопераційної ендолазерокоагуляції та використання техніки «сегментаціїделамінації» для видалення фіброваскулярних мембран мають важливий несприятливий вплив на результат операції.

Такі фактори, як калібр інструментів, тип лазерного коагулятора, використання ендодіатермії, кріоретинопексії, видалення внутрішьої межової мембрани, видалення периферії склоподібного тіла при склеродепресії, одночасне виконання факоемульсифікації з імплантацією інтраокулярної лінзи, проведення заднього капсулорексису, виконання дренуючої або релаксуючої ретинотомії, вид іригаційного розчину, ендотампонада силіконом, ендотампонада газами не мали суттєвого негативного впливу на результат операції.

У зв'язку з відносно невеликою кількістю хворих, прооперованих з використанням інгібіторів ендотеліального фактора росту (УБОБ) (Ьисепй8, ШуагЙ8), малоінвазивної бімануальної техніки 230 та 25О, низка ознак, наведених у таблиці, також траплялася рідко (їх позначено зірочкою). Однак їх клінічна важливість не викликає сумніву, тому значущість їх у балах визначали за допомогою евристичного оцінювання.

Експертна оцінка цих ознак була високою - 4,5 бала, тому що, згідно з нашим клінічним досвідом та сучасними даними літератури [13, 14], використання малоінвазивної техніки операції (за рахунок впровадження технологічних удосконалень) в комбінації 3 введенням інгібітора УБОБ дозволяє значно знизити травматичність операції, зменшити кількість інтрата післяопераційних ускладнень, покращити ефективність видалення склоподібного тіла, фіброваскулярних мембран та досягти стабілізації проліферативного процесу.

Необхідно зазначити, що значна кількість визначених нами соматичних факторів ризику у прогнозуванні результату хірургічного лікування хворих на діабетичну проліферативну ретинопатію узгоджується з літературними даними. До них, насамперед, нале- 
жать: наявність діабетичної нефропатії, анемія, тривалість діабету [15]. Так Ellen C. La Heij було проаналізовано одинадцять чинників, і зроблено висновок, що вік (за результатами багатофакторного аналізу) та 2 тип діабету (за результатами однофакторного аналізу) мають найбільш вагомий вплив на кінцевий зір [16]. Вивчити вплив більшої кількості системних факторів автори не змогли через невелику когорту пацієнтів. Разом 3 тим, D. Yorston не знайшов зв'язку між кінцевим зором та віком, національністю, використанням інсуліну, тривалістю діабету, гіпертензією, нефропатією, нейропатією, наявністю трофічних виразок кінцівок, палінням [16]. Загальновідомо, що тяжкий перебіг діабетичної ретинопатії є індикатором поганого метаболічного контролю та поганого загального стану пацієнта. Разом $з$ тим, в сучасній літературі є достовірні дані, які свідчать, що підтримання стійкої компенсації цукрового діабету може значно затримати (на 40-60 \%) розвиток ретинопатії. Своєчасно встановлений діагноз та досягнення максимальної компенсації можуть запобігти розвитку сліпоти більш ніж у 50 \% пацієнтів [18]. Отримані нами дані також підтверджують важливість повної компенсації цукрового діабету і лікування соматичних ускладнень, що може привести до покращення результатів операції.

Не викликає сумніву, що серед доопераційних чиників, які характеризують офтальмологічний статус пацієнта, найбільш важливими для прогнозування результату оперативного лікування $є$ ті, що характеризують анатомічний та функціональний стан центральної сітківки (гострота зору, відшарування макулярної сітківки, наявність центральної скотоми), ступінь прояву ішемії сітківки (неоваскуляризація сітківки, райдужки) та стан зорового нерва (загальне поле зору менше 300 градусів, повільна реакція зіниці на світло, атрофія зорового нерва, аферентний зіничний дефект Маркуса-Гуна, максимальний медикаментозний мідріаз менше 4 мм). Актуальність визначення саме цих факторів неодноразово підкреслювали Smiddy, Flynn, Thompson та інші, які вважали важливими передопераційними факторами ризику тяжкої втрати зору передопераційну гостроту зору $<5 / 200$, наявність неоваскуляризації райдужки, неоваскулярну глаукому та відшарування сітківки [19].

Багатофакторний аналіз, проведений D. Yorston, показав що доопераційний зір на оперованому та парному очах, відшарування макули та використання газів або силікону були пов 'язані з незадовільним кінцевим зором. Автори не знайшли зв'язку між кінцевим зором та станом прозорості кришталика, катаракталь- ною хірургією, передопераційним лазерним лікуванням та повторною вітректомією. Але ця модель розраховувала тільки незначну частку варіацій, які спостерігалися.

Складність виконання діабетичної вітректомії багато в чому залежить від поширеності вітреоретинальної тракціï. Kroll класифікує результати вітректомій залежно від типу тракційного відшарування центральної сітківки [20]. Отримані нами дані свідчать, що площинне тракційне відшарування макулярної сітківки є найбільш небезпечним відшаруванням для хірургії та важливим фактором незадовільного прогнозу.

Ellen C. La Heij з колегами довели, що найбільш важливими прогностичними офтальмологічними чинниками незадовільного прогнозу вітректомії є передопераційний зір менше 0,1, неоваскуляризація райдужки та відшарування макули більше 30 днів. Разом 3 тим, жоден з інтраопераційних чинників не мав значного впливу на поганий післяопераційний зір. П і с л я проведення багатофакторного аналізу неоваскуляризація райдужки визначилась найбільш важливим прогностичним фактором незадовільного результату хірургіï.

Згідно з результатами Mason J. О., післяопераційна максимально коригована гострота зору, тип цукрового діабету, тракційне відшарування сітківки, регматогенне відшарування сітківки, передопераційна лазерна коагуляція, післяопераційна неоваскуляризація диска зорового нерва або сітківки та наявність реоперацій визначились авторами як статистично не достовірні фактори ризику для незадовільного функціонального результату даної групи пацієнтів [21].

Не викликає сумніву, що особливості інтраопераційної техніки є одним з найбільш важливих чинників, що впливають на кінцевий функціональний результат хірургічного лікування діабетичних хворих. Нами встановлено несприятливий вплив на результат операції таких ознак, як: використання мономануальної техніки хірургії, неповне або часткове видалення фіброваскулярних мембран, використання під час операції перфтордекаліну, тривалість операції більше 1 години, невикористання повітряної ендотампонади сітківки, тривалість гідростатичного гемостазу більше 1 хвилини, проведення неповної інтраопераційної ендолазерокоагуляції та використання техніки «сегментації-деламінації» для видалення фіброваскулярних мембран. Це пов'язано з тим, що використання цих технічних прийомів (використання під час операції перфтордекаліну, тривалість операції більше 1 години, тривалість гідростатичного гемостазу 
більше 1 хвилини, проведення неповної інтраопераційної ендолазерокоагуляції) свідчить про ускладнений перебіг операції і необхідність проводити інтраопераційний гемостаз для боротьби 3 одним із найбільш небезпечних інтраопераційних ускладнень - профузним крововиливом. Використання мономануальної техніки хірургії не дає можливості ефективно та повноцінно видалити фіброваскулярні мембрани, а проведення «сегментації-деламінації» свідчить про наявність значної вітреоретинальної адгезії або регматогенного відшарування сітківки. Невикористання повітряної ендотампонади сітківки під час операції пов'язане $з$ проведенням ендотампонади силіконом або довгодіючими газами, що також свідчить про ускладнений перебіг операції та наявність тяжких інтраопераційних ускладнень (ятрогенні розриви сітківки, проведення релаксуючої ретинотомії, неповна реаплікації сітківки, за рахунок залишкових тракцій, крововиливи) які потребують проведення перманентної тампонади сітківки.

Слід відмітити отриманий нами суттєвий позитивний вплив на результат операції ознаки «передопераційне введення інгібітора VEGF», що підтверджується літературними даними і пояснюється патогенетично обумовленим неселективним блокуванням фактора росту ендотелію судин (VEGF). Це, в свою чергу, приводить до стабілізації процесу неоваскуляризації та зменшення набряку центральної сітківки [22].

Отримані нами результати та достатній клінічний досвід підтвердили високу ефективність сучасних методик хірургічного лікування хворих на ПДР, але невелика кількість прооперованих пацієнтів з використанням інгібіторів ендотеліального фактора росту (VEGF) (Lucentis, Novartis), малоінвазивної бімануальної техніки $23 \mathrm{G}$ та $25 \mathrm{G}$, видалення внутрішньої

\section{Лiтература.}

1. Global prevalence of diabetes: estimates for the year 2000 and projections for 2030 / S. Wild, G. Roglic, A. Green [et al.] / / Diabetes Care. - 2004. - Vol. 27. - P. 1047-1053

2. Риков С. О. Сліпота та слабкозорість. Шляхи профілактики в Україні / С. О. Риков. -Київ, 2011. - 268 с.

3. Blankenship G. The lens and pars plana vitrectomy for diabetic retinopathy complications / G. Blankenship, R. Cortez, R. Machemer. // Arch Ophthalmol. - 1979. Vol. - 97. - P. 12631267.

4. Сергиенко А. Н. Ранние результаты применения техники «иссечения блоком» в хирургическом лечении пролиферативной диабетической ретинопатии / А. Н. Сергиенко, А. Н. Рубан. // Офтальмол. журн. - 1998. - №> 3. - С. 184-187. 5. Глинчук Я. И. Клинические результаты применения жид- межової мембрани стверджує необхідність подальшого вивченя цієї проблеми.

За даними літератури відомо, що після вітректомії 3 дисекцією мембран покращення або стабілізація зору спостерігається у від 55 до 89 \% очей [23]. Незважаючи на удосконалення хірургічної техніки та операційного обладнання, функціональний результат вітректомії з приводу ПДР за останні 30 років збільшився незначно. Така тенденція до суттєвого поліпшення анатомічного результату при достатньо незначному покращенні зорових функцій була відмічена також раніше при хірургії первинного регматогенного відшарування сітківки [24]. Затримка часу від перших клінічних ознак до проведення хірургічного лікування, а також збільшення частоти ураження макулярної сітківки (внаслідок тракцій або ішемії) $є$ одними з причин незначного покращення зору після операції.

Висновки: 1. Провідними біологічними та системними факторами в оцінці ризику перебігу та результату вітректомії є тривалість клінічних проявів захворювання, загальний стан при госпіталізації, виразність порушень функції нирок, а також наявність нейропатії та анемії.

2. Встановлено несприятливий вплив на результат хірургічного лікування хворих на діабетичну проліферативну ретинопатію чинників, що характеризують анатомічний та функціональний стан центральної сітківки, ступінь прояву ішемії сітківки та зорового нерва.

3. Використання сучасних малоінвазивних технік хірургічного лікування діабетичної проліферативної ретинопатії з використанням інгібіторів фактора росту ендотелію судин (УБОБ) є ефективним та перспективним напрямком лікування цієї тяжкої патології.

ких перфторорганических соединений в комплексном хирургическом лечении тракционных отслоек сетчатки с захватом макулярной области при пролиферативной диабетической ретинопатии І Глинчук Я. И., Метаев С. А., Саркисян А. И. ІІ Офтальмохирургия. - 199б. - º 2. - С. 7-12. 6. Steinmetz R. L. Vitrectomy for diabetic trartion retinal detachment using the multiport illumination system I R. L. Steinmetz, S. Grizzard, M. E. Hammer Ophthalmology.- 2002. \b1. 109. - P. 2303-2307.

7. Бевацизумаб (авастин) в комплексном хирургическом лечении больных с пролиферативной стадией диабетической ретинопатии I С. С. Родин, В. С. Асланова II Український медичний альманах. - Луганск. - 200S. - Т. 11, № 3. - С. 126-12S. 
8. Complications of vitreous surgery for diabetic retinopathy. II. Postoperative complications / A. P. Schachat, R. T. Oyakawa, R. G. Michels, T. A. Rice// Ophthalmology. - 1983. - Vol. 90. P 522-530.

9. Recent outcomes of vitreous surgery for diabetic retinopathy / H. Oda, K. Konno, K. Mitsui [et al.] // Nippon Ganka Gakkai Zasshi. - 2005. - Vol. 109. - P. 603-612.

10. Causes of severe visual loss in the early treatment diabetic retinopathy study: ETDRS report no. 24. Early Treatment Diabetic Retinopathy Study Research Group / Fong D. S., III Ferris F. L., M. D. Davis, E. Y. Chew // Am. J. Ophthalmol. 1999. - Vol. 127. - P. 137-141.

11. Минцер О. П. Інформаційні технології в хірургії / О. П. Минцер, В. 3. Москаленко, С. В. Веселий. - В 10 книгах «Інформаційні технології в охороні здоров'я і практичній медицині». - Кн.3. - К. : Вища школа, 2004. - 423 с.

12. Рубан А. М. Інформаційне забезпечення стратегії визначення оптимальної тактики хірургічного лікування хворих 3 проліферативною діабетичною ретинопатією / А. М. Рубан // Медична інформатика та інженерія - $\mathrm{N}^{\circ} 3$. 2011. - C. 56-62.

13. Bevacizumab pretreatment in vitrectomy with silicone oil for severe diabetic retinopathy / P. Yeh, C. Yang, Y. Lin [et al.] // Retina. - 2009. - Vol. 29, № 6. - P. 768-774.

14. / S. Shaikh, S. Ho, P. P. Richmond [et al.] Untoward outcomes in 25-gauge versus 20-gauge vitreoretinal surgery // Retina. 2007. - Vol. 27. - P. 1048-1053.

15. Aiello L. P. Sytemic considerations in the management of diabetic retinopathy / L. P. Aiello, M. T. Cahill, J. S. Wong. Am. J. Ophthalmol. - 2001. - Vol. 132. - P. 760-776.

16. Clinical variables and their relation to visual outcome after vitrectomy in eyes with diabetic retinal traction detachment / E. C. La Heij, S. Tecim, A. G. Kessels [et al.] // Graefes Arch.
Clin. Exp. Ophthalmol. - 2004. - Vol. 242. - P. 210-217.

17. Predictive clinical features and outcomes ofvitrectomy for proliferative diabetic retinopathy / D. Yorston, L. Wickham, S. Benson [et al.] // Br. J. Ophthalmol. - 2008. - Vol. 92. - P. 365 368.

18. UK Prospective Diabetes Study Group Tight blood pressure control and risk of macrovascular and microvascular complications in type 2 diabetes. UKPDS 38 // BMJ. - 1998. Vol. 31:317. - P. 703-713.

19. Prognostic indicators of success and failure in vitrectomy for diabetic retinopathy / J. T. Thompson, C. L. Auer, S. de Bustros [et al.] // Ophthalmology. - 1986. - Vol. 93. - P. 290-295. 20. Kroll P. Vitreopapillary traction in proliferative diabetic vitreoretinopathy / P. Kroll, W. Wiegand, J. Schmidt// Br. J. Ophthalmol. - 1999. - Vol. 83. - P. 261-264.

21. Visual outcome and risk factors for light perception and no light perception vision after vitrectomy for diabetic retinopathy / III J. O. Mason, C. T. Colagross, T. Haleman [et al.] // Am. J. Ophthalmol. - 2005. - Vol. 140. - P. 231-235.

22. Microincision vitrectomy surgery and intravitreal bevacizumab as a surgical adjunct to treat diabetic traction retinal detachment/Y. Oshima, C. Shima, T. Wakabayashi [et al.] // Ophthalmology. - 2009. - Vol. 116. - P. 927-938.

23. First operation anatomic success and other predictors of postoperative vision after complex retinal detachment repair with vitrectomy and silicone oil tamponade / I. U. Scott, H. W. Flynn, M. Lai [et al.] // Am. J. Ophthalmol. - 2000. - Vol. 130. P. 745-750.

24. Сергиенко А. Н. Проліферативні вітреоретинальні процеси при регматогенному відшаруванні сітківки, діабетичній ретинопатії і травмі ока: автореф. дис. на здобуття наукового ступеня д-ра мед. наук / А. Н. Сергиенко. - Одеca, 2009. 